\title{
Analysis on Ex-Dividend Phenomenon before and During COVID-19 Pandemic in Indonesia (Study on Index IDX High Dividend 20)
}

\author{
Ratna Suwendiyanti ${ }^{1 *}$, Rilla Gantino ${ }^{2}$ \\ ${ }^{1}$ Post-Graduate Student, Accounting Department, Faculty of Economics and Business, Esa Unggul University, Indonesia \\ ${ }^{2}$ Lecturer, Accounting Department, Faculty of Economic and Business, Esa Unggul University, Indonesia
}

\section{Article History \\ Received: 22.11 .2021 \\ Accepted: 30.12 .2021 \\ Published: 02.01.2022 \\ Journal homepage: https://www.easpublisher.com}

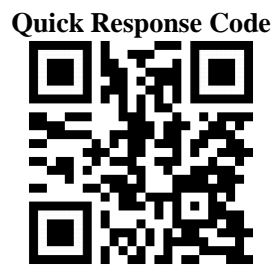

Abstract: This study aims to find the difference in stock price and trading volume around the ex-dividend date before and during the COVID-19 pandemic. We used event study methods with 100 days estimation period and 11 days event period. The stock price is observed through abnormal return, and trading volume is observed through trading volume activity. The research population is the companies listed on the index IDX High Dividend 20 in the year 2021, and samples are 20 companies on the index with 85 cash dividend events. Normality test used Kolmogorov-Smirnov test, while hypotheses test used Paired T-test and Wilcoxon signed-rank test. The study result shows a significant difference in stock price before, during, and after the ex-dividend date before the pandemic but not during the pandemic. The study also shows no significant difference in trading volume before, during, and after the exdividend date, whether before or during the pandemic.

Keywords: Ex-dividend, abnormal return, trading volume activity, COVID-19.

Copyright (C) 2022 The Author(s): This is an open-access article distributed under the terms of the Creative Commons Attribution 4.0 International License (CC BY-NC 4.0) which permits unrestricted use, distribution, and reproduction in any medium for non-commercial use provided the original author and source are credited.

\section{INTRODUCTION}

Stock price reflects the investor's expectation on earnings, dividends, and interest that will happen. The result of that investor's estimation on those three things will result in the appropriate stock price. Likewise, trading activity is also one of the indicators that can be used to assess the stock's performance. Based on the Mixture of Distribution Model by Chen, Firth, and Rui, stock price and trading activity should have a positive relationship that changes as new information comes out (Darmawan, 2018).

One of the information that can influence prices and the number of shares movement is a corporate action, such as right issue, distribution of bonus stock, stock split, and dividend distribution (Nuraya \& Larasati, 2018). The stock market will react to the presence of corporate action information shown on the trading volume, stock prices changes, and the difference in the company's profit (Mahala et al., 2015). One of the corporate actions that are pretty important to be known by the investor is a dividend, which distributes the company's profit to stockholders based on the stock they owned (Andini et al., 2017). There are various theories regarding market reaction to the distribution of a company's dividend. Nuraya and Larasati (2018) explained that based on signaling theory, dividend distribution could influence investors because it contains signal information regarding the company's prospects and profit in the future. Based on the agency cost model, a dividend is a tool to monitor management behavior and minimize agency costs arising from the potential of conflict of interest between shareholders and management (Hitten, 2016). distribution of cash dividends has various essential dates, namely cum-dividend date, ex-dividend date, recording date, and payment date. The ex-dividend date is when investors who purchase shares of companies that distribute dividends on that day are no longer entitled to receive dividends (Tandelilin, 2017).

The volume of stock trading activity and abnormal return can be used to see investors' reactions to information, such as dividend information on particular dates. Campbell and Beranek (1955) disclose the assumption that the stock price has decreased on the ex-dividend date by the amount of the dividends distributed. Both conducted researches to prove this assumption and found that the average share price that fell on the ex-dividend date was around 90 percent of the dividends distributed when the stock market was relatively stable. The decline in share prices generally occurs because, after the ex-dividend date, most investors take profit-taking from the difference between the stock price and the dividends they get. The investors usually hold their shares until the cum-dividend date 
(one day before the ex-dividend date) and sell the shares on the ex-dividend date (Istahargyo \& Wirakusuma, 2019). Sih et al. (2019) research shows no difference in abnormal return and trading volume activity on the ex-dividend date. Still, differences in trading volume activity on the cum-dividend date are found.

The Indonesia Stock Exchange has various stock indices. The stock index is a statistical measure that reflects the price movement of a group of stocks as a whole. The stocks are selected based on specific criteria and will be evaluated periodically. One of the stock indexes owned by the Indonesia Stock Exchange is IDX High Dividend 20, which was launched on May 17, 2018. This index measures the stock price performance of 20 companies that have distributed cash dividends for the last three years and have high dividend yields. This index will be attractive to investors, especially those who expect high profits from high dividend yields. This index has also just been launched, so it is interesting to observe, especially the effect of dividend distribution events due to high yields that can trigger investors to make investment decisions. This index has also been used in research conducted by Nurfadillah and Nuzula (2019). Both consider that this index can represent the market reaction to cash dividend distribution events in the Indonesian stock market. They researched companies included in the IDX High
Dividend 20 index in 2018. They found significant differences in abnormal returns before and after the exdividend date, which means the ex-dividend date impacts abnormal returns.

Changes in stock prices and stock trading activities also always occur before economic changes, which shows a strong relationship between stock prices and macroeconomic performance (Tandelilin, 2017). The performance of the capital market will react to macroeconomic changes, where the state of a country also influences macroeconomic conditions. As is well known, at the end of 2019, the COVID-19 virus was found in Wuhan, China. The virus has a high and fast rate of spread where the WHO (World Health Organization) has declared COVID-19 as a global health emergency (Saraswati, 2020). The COVID pandemic has had a massive impact on various sectors around the world, as well as on stock markets in different parts of the world, which experienced a drastic decline in stock prices, such as most shares in Vietnam (Anh \& Gan, 2020), the S\&P 500 Index which fell $34 \%$. In the United States (Capelle-Blancard \& Desroziers, 2020) and in Indonesia itself where the JCI experienced a decline of $26.43 \%$ (Saraswati, 2020). Even so, the JCI and trading volume gradually increased, especially in September, which is shown in the following figure:

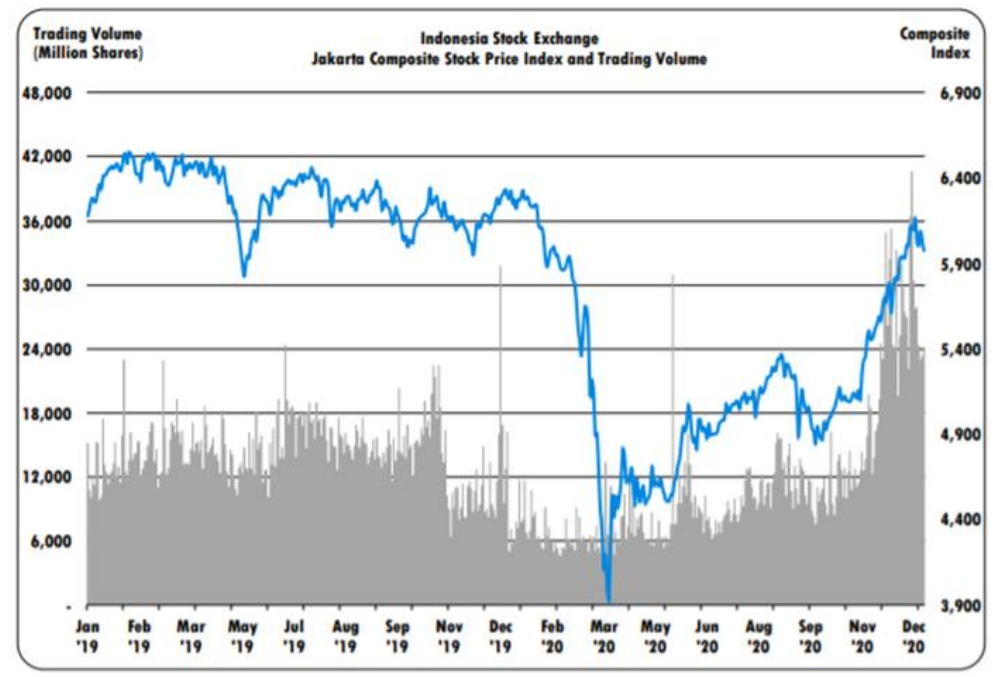

Figure 1: Graph of JCI Stock Price and Trading Volume year 2019 - 2020 (Source: IDX Statistics 2020)

In contrast to the decline in the JCI caused by the COVID-19 pandemic, the number of capital market investors experienced a high increase. Based on the investor demographic released by The Indonesia Central Securities Depository, the capital market investors increased by $56.21 \%$ in 2020 , the highest growth compared to previous years. The increasing number of investors and the JCI is a gap phenomenon in this study. Even though the economic conditions are not stable during the pandemic, the stock investment activities are actually getting better with a significant increase in capital market investors.

\section{LITERATURE REVIEW}

Various research on this matter has been done after Campbell and Beranek researched in 1955. In line with the study conducted by Campbell and Beranek, Ngoc and Cuong (2016) found that dividend distribution announcements positively affect the announcement date, and there is an increase in stock 
prices to approach the ex-dividend date and then decrease since the ex-dividend date. This research supports the dividend relevance theory where dividend policy affects firm value, which can help financial managers to determine the optimal dividend policy that will improve company performance. Agarwal (2020) and Tinashe (2015) also found that the ex-dividend date affects price changes. They found an upward trend in prices before the ex-dividend date followed by a decrease in stock prices after the ex-dividend, where the percentage decline in stock prices on the ex-dividend date. Ex-dividend date on average 90 percent of the dividends distributed. Isaksson and Islam (2013), who researched the stock market in several countries, found abnormal returns and short-term trading around exdividends on the Tokyo Stock Exchange and the London Stock Exchange but did not find the same thing on the New York Stock Exchange and the Shanghai Stock Exchange. In line with the findings of Isaksson and Islam (2013) on the New York Stock Exchange and Shanghai Stock Exchange, Nuraya and Larasati (2018) state that there is no significant difference in abnormal returns before and after dividend disclosures and exdividend dates. Octaviani et al., (2019), who examined stock returns before and after the ex-dividend date in the Property, Real Estate, and Construction industries, found no significant difference between the average stock returns before and after the ex-dividend date.

Research on dividend distribution conducted outside Indonesia is generally related to taxes on dividend receipts or other dividend theories. A previous study found that in the tax-free stock market, there were abnormal returns on ex-dividend days (Dupuis, 2019), and there was a decrease in the average share price by the number of dividends distributed (Kreidl, 2020). Meanwhile, there is no difference in returns on the exdividend date in markets that apply the same tax rate between dividends and capital gains (García Blandón et al., 2011). The research conducted by Chen et al., (2013) found that differential tax is an essential factor that affects stock prices and investor behavior around the ex-dividend day. The investors with a high tax bracket sell shares on the cum-dividend day and then buy shares on the ex-dividend day. In contrast, investors with low tax brackets trade the other way around. Research conducted in the BRIC zone (Brazil, Russia, India, China) to examine the phenomenon of exdividend days against various theories, found that in this zone, the phenomenon of ex-dividend days supports the dividend-capturing theory and disposition effect theory (Cherkasova \& Petrukhin, 2017).

Several studies do not only focus on abnormal returns, but these studies also test the volume of stock trading activity that can be used to see investors' reactions in responding to information. Tamara et al., (2020) researched stock prices and trading volumes on ex-dividend days at pharmaceutical companies in various countries revealed no abnormal trading volume on the ex-dividend date or the previous day. In contrast to this research, Istahargyo and Wirakusuma (2019), who researched companies in the LQ45 index in 2017, found a significant difference between stock trading volumes before and after the ex-dividend date. Chen et al., (2013) also found that there was excess transaction volume around ex-dividend days.

The economic condition is highly affected by the current pandemic, which affects the performance of the capital market worldwide but shows an interesting fact that there is a very significant increase in capital market investors. Eugster et al. (2020) researched the western European market during COVID-19. They found that the pattern of stock returns on ex-dividend dates during the pandemic had doubled compared to previous years, and changes in stock prices mainly were caused by dividend-seeking investors. As the pandemic happened in 2019 and is still going on, the literature on the market reaction to ex-dividend date events is still minimal and much needed. This paper intended to contribute to the literature on the market reaction on exdividend date during the COVID-19 pandemic and find whether the evidence from Western Europe will also be found in Indonesia.

\section{METHODOLOGY}

This study was conducted to examine the impact of the ex-dividend date event during the pandemic in 2020 and before the pandemic in 2018 and 2019 on stock prices and stock trading volume on stocks listed on the Indonesia Stock Exchange that distributed dividends during these events. The research object is companies listed on the IDX High Dividend 20 index 2021, which are observed before and after the exdividend date before and during the pandemic. The period after the ex-dividend during the pandemic as an independent variable and stock prices observed through abnormal returns and stock trading volume observed through trading volume activity as the dependent variable.

The population is companies included in the IDX High Dividend 20 index in 2021. The sample is companies in the index that distribute dividends before and during the pandemic. The sample selection was carried out by the purposive sampling method; a sampling technique carried out based on the characteristics of the data adapted to the purpose or research problem (Saleh, 2017). The sampling criteria is the company has to be listed on the Indonesia Stock Exchange in the IDX High Dividend 20 index 2021, distributed cash dividends in a row from 2018 to 2020 and did not announce any other corporate actions during the estimation and event period. The checking results found that the samples to be studied were 19 companies with 23 interim dividend distribution events and 57 final dividend distribution events. Before starting the research, the stock price and trading volume data used are re-examined whether there are other corporate 
actions around the estimation period and the event period.

The re-examination results found that the date of the corporate action other than the distribution of dividends by the sample companies did not occur on days in the estimation period and the event period. The number of final samples studied became 20 companies with 25 interim dividend distribution events and $60 \mathrm{cash}$ dividend distribution events.

The research conducted is an event study undertaken to examine the impact of an event with an estimated time of 100 days. The observation period used is 11 days, namely five days before the exdividend date, the ex-dividend date before the pandemic, five days after the ex-dividend date for each period before and during the pandemic. The data used is secondary data obtained through the official website of the Indonesia Stock Exchange, The Indonesian Central Securities Depository, and investing.com. Based on the previous literature, The normality test of the data was carried out using the Kolmogorov-Smirnov test. The data with normal distribution was then tested using paired sample t-test. Wilcoxon signed-rank test will be used if the data is not normally distributed.

Abnormal returns were calculated using the Market Model using the following formula (Nuraya \& Larasati, 2018):

$A R_{i, t}=R_{i t}-E\left(R_{i t}\right)$

Where ARi, $\mathrm{t}=$ Abnormal return of securities $\mathrm{i}$ during day $\mathrm{t}$; Rit $=$ Actual return of securities $\mathrm{i}$ during day $t ; E($ Rit $)=$ Expected return of securities i during day t.

To calculate the abnormal return, it is necessary first to know the actual return along with the expected return. The following formula calculates the actual return:

$$
\text { Rit }=\frac{P_{i t-P_{i t-1}}}{P_{i t-1}}
$$

Where $\mathrm{R}_{\mathrm{it}}=$ Stock return of securities $\mathrm{i}$ during day $\mathrm{t} ; \mathrm{P}_{\mathrm{it}}=$ Stock price of securities $\mathrm{i}$ during day $\mathrm{t}$; $\mathrm{P}_{\mathrm{it}-1}=$ Stock price of securities i during day $\mathrm{t}-1$.
To be able to calculate the expected return, it is necessary first to obtain market return information which can be known by using the following calculations:

$$
R m t=\frac{I H S G_{t}-I H S G_{t-1}}{I H S G_{t-1}}
$$

Where $\mathrm{R}_{\mathrm{mt}}=$ market return during day $\mathrm{t}$; $\mathrm{IHSG}_{\mathrm{t}}$ $=\mathrm{JCI}$ during day $\mathrm{t}$; $\mathrm{IHSG}_{\mathrm{t}-1}=\mathrm{JCI}$ during day $\mathrm{t}-1$.

After knowing the market return, then the expected return can be calculated using the following formula:

$E\left(R_{i t}\right)=\alpha i+\beta i R_{m t}$

Where $E\left(R_{i t}\right)=$ Expected return of securities $i$ during day $\mathrm{t} ; \alpha \mathrm{i}=$ alfa of securities $\mathrm{i} ; \beta \mathrm{i}=$ beta estimation of securities $\mathrm{i} ; \mathrm{R}_{\mathrm{mt}}=$ market return during day $t$.

After these calculations are made and abnormal returns are obtained for each security, it is necessary to calculate the average abnormal return, which can be calculated using the following formula:

$$
A A R_{t}=\frac{1}{n} \sum_{t=1}^{n} 1 \frac{A R_{i t}}{n}
$$

Where $\mathrm{AAR}_{\mathrm{t}}=$ Average abnormal return on day $\mathrm{t} ; \mathrm{AR}_{\mathrm{it}}=$ Abnormal return of securities $\mathrm{i}$ during day t.

The stock trading volume is measured by Trading Volume Activity (TVA), which is calculated using the following formula (Istahargyo \& Wirakusuma, 2019):

$T V A=\frac{\text { Number of shares traded }}{\text { Outstanding shares }}$

\section{RESULT AND DISCUSSION}

The period before the pandemic uses 2018 and 2019 data and the combined data for both years and the pandemic period using 2020 data. Each observation year is grouped into three groups: before the exdividend date, the ex-dividend date, and after. Against this group of data, a normality test was carried out using the Kolmogorov-Smirnov test to determine the normality of the data distribution. The results of the normality test can be seen in the summary table of test results in table 1 below:

Table 1: Result of Normality Test

\begin{tabular}{|l|l|l|l|l|}
\hline \multirow{2}{*}{ Description } & \multicolumn{2}{|l|}{ Abnormal Return } & Trading Volume Activity \\
\cline { 2 - 5 } & Sig. & Distribution & Sig. & Distribution \\
\hline Before Pandemic \\
\hline $\mathbf{2 0 1 8}$ & 0.190 & Normal & $<0.001$ & Abnormal \\
\hline Before ex-date & 0.110 & Normal & $<0.001$ & Abnormal \\
\hline Ex-date & 0.200 & Normal & $<0.001$ & Abnormal \\
\hline After Ex-date & 0.5 & Normal \\
\hline $\mathbf{2 0 1 9}$ & 0.044 & Abnormal & 0.200 & Abnormal \\
\hline Before ex-date & 0.007 & Abnormal & $<0.001$ & A \\
\hline Ex-date & \multicolumn{5}{|l}{} \\
\hline
\end{tabular}




\begin{tabular}{|l|l|l|l|l|}
\hline After Ex-date & 0.200 & Normal & 0.008 & Abnormal \\
\hline During Pandemic \\
\hline 2020 \\
\hline Before ex-date & 0.200 & Normal & $<0.001$ & Abnormal \\
\hline Ex-date & 0.200 & Normal & $<0.001$ & Abnormal \\
\hline After Ex-date & 0.200 & Normal & $<0.001$ & Abnormal \\
\hline
\end{tabular}

Source: Author's test result

The table shows abnormal return data for 2018 and 2020 are distributed normally, while data for 2019 and the combined data are not distributed normally. Results for TVA data shows that the data for all observation year are not distributed normally. The observation period with all normally distributed data will be tested for hypotheses using the paired sample ttest. The hypothesis will be tested using the Wilcoxon signed-rank test for the observation period whose data are not normally distributed. Hypothesis testing for each observation period is divided into two test pairs: before the ex-dividend date with the ex-dividend date and the ex-dividend date after the ex-dividend date.

Hypothesis testing for the stock price variable was carried out with two tests: the 2018 and 2020 data tested using the paired sample t-test, while the 2019 data and the combined data for the pre-pandemic period were tested using the Wilcoxon signed-rank test. The results of the paired sample t-test tests can be seen in the following table:

Table 2: Result of Paired Sample T-test

\begin{tabular}{|l|l|l|l|l|}
\hline Description & $\mathbf{t}_{\text {test }}$ & $\begin{array}{l}\mathbf{t}_{\text {table }} \\
(\mathbf{0 , 0 5})\end{array}$ & Sig. (2-sided) & Result \\
\hline Before Pandemic & & & & Significantly different \\
\hline 2018 & 3.710 & 2.056 & $<0.001$ & Significantly different \\
\hline $\begin{array}{l}\text { Before and after ex- } \\
\text { date }\end{array}$ & -3.097 & 2.056 & 0.005 & \\
\hline Ex-date and after & & & & Significantly different \\
\hline During Pandemic & 5.309 & 2.045 & $<0.01$ & No significant difference \\
\hline 2020
\end{tabular}

Source: Author's test result

Table 2 shows the results of the paired sample t-test for normally distributed data. For 2018 data, the test results for the first and second pairs show a significance value of $<0.001$ and 0.005 ; both are smaller than $0.05(<0.05)$. The two testing pairs also show the significance value of the t-test $>\mathrm{t}$-table, which can be concluded that there is a significant difference in stock prices before, during, and after the ex-dividend date in
2018. For 2020 data, the first test pair shows t-test $5.309>$ t-table 2.045 and significance value $<0.01$, which is smaller than $0.05(<0.05)$. The second test pair shows t-test $0.745<$ t-table 2.045 and a significance value of 0.462 , which is more significant than 0.05 , so it can be concluded that there is a significant difference in stock price before and after the ex-dividend date, but not after the ex-dividend date.

Table 3: Result of Wilcoxon Signed Rank Test for Abnormal Return

\begin{tabular}{|l|l|l|}
\hline Description & Asymp. Sig. (2-tailed) & Result \\
\hline 2019 & & \\
\hline Before and after the ex-date & $<0.001$ & $\begin{array}{l}\text { Significantly } \\
\text { different }\end{array}$ \\
\hline Ex-date and after & 0.003 & $\begin{array}{l}\text { Significantly } \\
\text { different }\end{array}$ \\
\hline Combination if 2018 \& 2019 & & $\begin{array}{l}\text { Significantly } \\
\text { different }\end{array}$ \\
\hline Before and after the ex-date & $<0.001$ & Significantly different \\
\hline Ex-date and after & $<0.001$ & \multicolumn{2}{|l}{} \\
\hline
\end{tabular}

Source: Author's calculation

Table 3 shows the Wilcoxon Signed Rank Test results for abnormal return data that is not distributed normally. The 2019 data result for the two test pairs shows significance values of $<0.001$ and 0.003 ; both are smaller than $0.05(<0.05)$, which concluded that there is a significant difference in stock prices before, during, 
and after the ex-dividend date in 2019. For the 2018 and 2019 combined data, the results of hypothesis testing for both test pairs show a significance value of $<0.001$ for both test pairs, where the value is less than 0.05 $(<0.05)$.

The results of statistical testing on abnormal returns in this study accept hypothesis $\mathrm{H} 1$, which states that there are significant differences in stock prices before, during, and after the ex-date before the pandemic. The test results align with research conducted by Nurfadillah \& Nuzula (2019), which found significant differences in abnormal returns before and after the ex-date. The dividend distribution announcement made by the company is proven to have information content so that it is responded to by the market and produces abnormal returns (Hartono, 2018).
The results of statistical tests on abnormal returns during the pandemic show a significant difference in stock prices before and during the ex-date, but not after the ex-date, which rejects the $\mathrm{H} 2$ hypothesis. The test results are partially in line with the research of García Blandón et al., (2011), Nuraya \& Larasati (2018), and Octaviani et al., (2019), which states that there is no significant difference in abnormal returns before, during, and after the ex-date.

The normality test that has been carried out shows that the data for TVA in all years of observation have abnormal distribution. The hypothesis test carried out for all years of observation is the Wilcoxon signedrank test. The summary of test results can be seen in the following table:

Table 4: Result of Wilcoxon Signed Rank Test for TVA

\begin{tabular}{|l|l|l|}
\hline Description & Asymp. Sig. (2-tailed) & Result \\
\hline Before Pandemic & & \\
\hline 2018 & & \\
\hline Before and after the ex-date & 0.810 & No significant difference \\
\hline Ex-date and after & 0.501 & No significant difference \\
\hline 2019 & & \\
\hline Before and after the ex-date & 0.755 & No significant difference \\
\hline Ex-date and after & 0.673 & No significant difference \\
\hline Combination if 2018 \& 2019 & & \\
\hline Before and after the ex-date & 0.837 & No significant difference \\
\hline Ex-date and after & 0.804 & No significant difference \\
\hline During Pandemic & & \\
\hline 2020 & & \\
\hline Before and after the ex-date & 0.530 & No significant difference \\
\hline Ex-date and after & 0.349 & No significant difference \\
\hline
\end{tabular}

Source: Author's test result

Table 4 shows a summary of the results of hypothesis testing for the stock trading volume. The significance value for all years of observation, both before and during the pandemic, is more significant than $0.05(>0.05)$. These results reject both the $\mathrm{H} 3$ and H4 hypotheses, meaning that there is no significant difference in stock trading volume before, during, and after the ex-date before and during the pandemic. The results of this test are in line with research conducted by Sih et al., (2019) and Tamara et al., (2020), who found no difference in trading volume activity around the exdate.

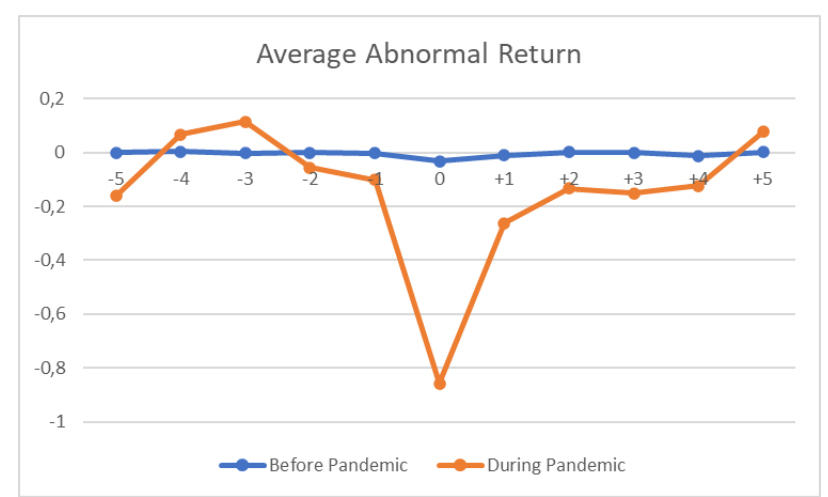

Figure 2: Average Abnormal Return Before and During Pandemic Source: data processed by the Author

Figure 2 shows that the lowest average abnormal return (AAR) occurred on the ex-date, either before or during the pandemic. It is in line with research by Campbell \& Beranek (1955), which proves the assumption that stock prices decline on the ex-date. Figure 2 also shows that either before or during the 
Ratna Suwendiyanti \& Rilla Gantino, East African Scholars J Econ Bus Manag; Vol-5, Iss-1 (Jan, 2022): 1-10

pandemic, there was no upward trend in prices until the cum-date and then a decline starting from the ex-date. This study contrasts with Eugster et al., (2020), which examined price patterns around the ex-date during COVID-19. His research found that the pattern of stock returns on ex-dates doubled compared to previous years. Contrary to his research, this study found AAR gradually decreased on the cum-date to the ex-date, then rose again after the ex-date, both before and during the pandemic. Although there is a significant difference in stock prices around the ex-date, the yield on the ex- date is negative, in line with research by Tamara et al., (2020). Compared with stock trading activities shown in Figure 3 below, before the pandemic, TVA gradually increased from the second day before the ex-date until it reached the highest TVA on the ex-date. When observed together, on the first day before the ex-date (cum-date), AAR decreased compared to the previous day, but TVA increased, so investors were likely to release their shares on that day. On the ex-date, the high volume was most likely due to investors selling their shares so that the AAR decreased.

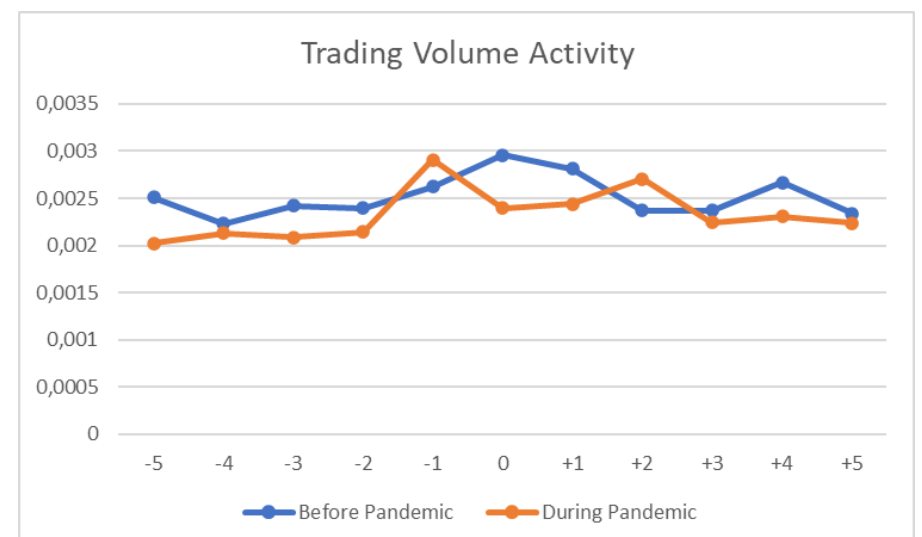

Figure 3: Trading Volume Activity Before and During Pandemic Source: data processed by the Author

Figure 3 shows that many of the average abnormal returns are negative in the pre-pandemic period and during the pandemic, indicating that investors' actual returns are smaller than expected. Positive or negative abnormal returns indicate the direction of the market reaction to events. A negative abnormal return means an event containing bad news (Hartono, 2018), which can be seen in the following table; in 2019, several companies whose dividend nominal fell, including INDF, WSBP, and TOWR. The nominal dividend in 2020 also decreased, including CPIN, ITMG, WSBP, and UNVR.

Table 5: Dividend distributed on the observation period

\begin{tabular}{|c|c|c|c|c|c|c|}
\hline \multirow[t]{2}{*}{ Code } & \multicolumn{2}{|l|}{2018} & \multicolumn{2}{|l|}{2019} & \multicolumn{2}{|l|}{2020} \\
\hline & Interim & Final & Interim & Final & Interim & Final \\
\hline ADRO & & 65.39 & 33.99 & 56.16 & 65.48 & 44.13 \\
\hline ASII & 60.00 & 130.00 & 57.00 & 154.13 & 27.00 & 157.00 \\
\hline BBCA & 85.00 & 175.00 & 100.00 & 255.00 & 98.00 & 455.00 \\
\hline BBNI & & 255.56 & & 201.29 & & 206.24 \\
\hline BBRI & & 106.75 & & 132.17 & & 168.20 \\
\hline BMRI & & 199.03 & & 241.22 & & 353.34 \\
\hline CPIN & & 56.00 & & 118.00 & & 81.00 \\
\hline DMAS & & 6.50 & 21.00 & 21.00 & 25.00 & 21.00 \\
\hline HMSP & & 107.30 & & 117.20 & & 119.80 \\
\hline INDF & 65.00 & 237.00 & & 171.00 & & 278.00 \\
\hline INTP & & 700.00 & & 550.00 & 225.00 & 500.00 \\
\hline ITMG & $1,420.00$ & $1,840.00$ & 705.00 & $2,045.00$ & 307.00 & 570.00 \\
\hline KLBF & & 25.00 & & 26.00 & 6.00 & 20.00 \\
\hline WSBP & & 30.60 & & 22.50 & & 8.22 \\
\hline PGAS & & 31.61 & & 56.99 & & 41.56 \\
\hline PTBA & & 318.52 & & 339.63 & & 326.46 \\
\hline TLKM & & 167.66 & & 163.82 & & 154.07 \\
\hline TOWR & 6.00 & 87.61 & 6.00 & 17.52 & 6.00 & 17.86 \\
\hline UNTR & 365.00 & 611.00 & 408.00 & 828.00 & 171.00 & 805.00 \\
\hline UNVR & 410.00 & 505.00 & 430.00 & 775.00 & 87.00 & 107.00 \\
\hline
\end{tabular}

Notes: in IDR (Indonesia Rupiah)

Source: The Indonesia Central Securities Depository, processed by the Author 
As seen in Figure 3, what happened during the pandemic contrasted with before, where the highest TVA occurred on the cum-date. The high TVA coupled with a decrease in abnormal returns means that most investors who make transactions sell the company's shares that distribute the dividends. The absence of a significant effect of dividend distribution on stock trading volume shows that dividend distribution events always carried out by companies on the IDX High Dividend 20 index every year are not very attractive for investors to invest. Although it looks volatile on the graph, the transactions made around the ex-date are not excessive to not cause abnormal trading volume. When associated with dividend theory, it supports the dividend irrelevance theory, which states that dividend policy does not affect the stock market. The result of the statistic test for the pandemic period which shows that there is a significant difference in stock prices before and during the ex-date, but not after the ex-date shows that this study also supports the clientele effect, where investors have a preference to avoid dividend distributions because the dividend distribution is carried out annually with a high nominal value. It causes investors to release their shares more quickly to save taxes, which shows that this study also supports the tax effect theory.

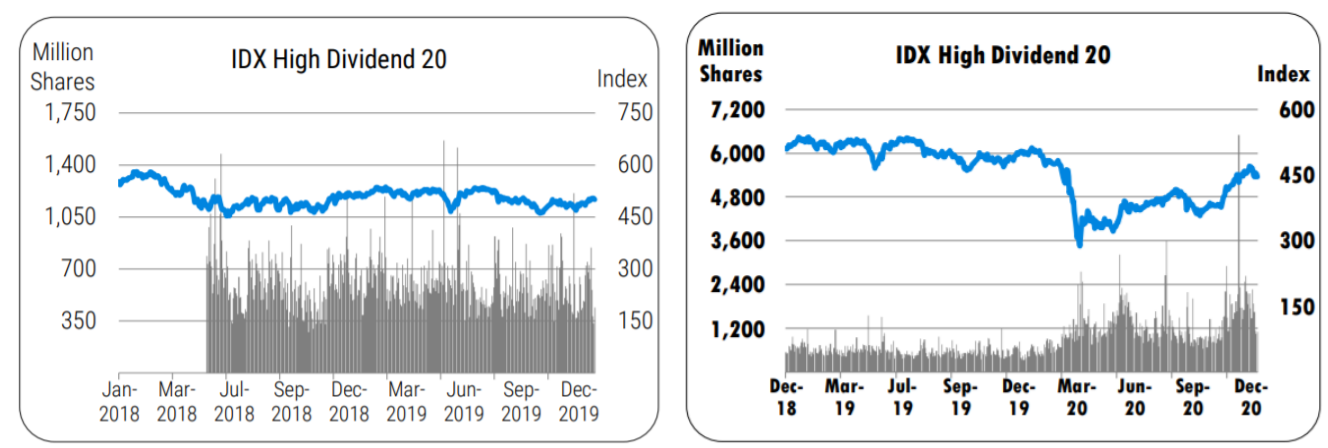

Figure 4: IDX High Dividend 20 Index Performance from issued date until 2020 Source: IDX Statistics 2019 and 2020

The results, which show significant differences in stock prices before, during, and after the ex-date before the pandemic but not during the pandemic, indicate that the COVID-19 pandemic impacts the stock market. The COVID-19 pandemic has affected various industries, where the property industry sector experienced the highest decline, where the index decreased by $33.32 \%$ (Saraswati, 2020). Figure 4 shows the performance of the IDX High Dividend 20 index before and during the pandemic, where during the pandemic, it decreased as happened in the IDX Composite. The decline in index performance can make investors more careful in investing. Investors prefer to invest in companies in specific industries that are considered to have good performance during the pandemic, such as the consumer goods, telecommunications, and health industries (Tambunan, 2020), or in blue-chip companies than taking advantage of dividends. It shows on the statistic test results on stock prices, where during the pandemic, the difference of the stock process only happens before the ex-date, but not the after. The investor prefers to take profit from the abnormal return that happens before the ex-date and sell their stocks before the ex-date to evade the dividend distribution which is why it is no significant difference in stock price after the ex-date.

The increasing number of COVID-19 cases and activity restrictions have resulted in unstable economic conditions, which investors see as a high risk in investing. The research results of the Danareksa Research Institute (2020) show that the COVID-19 pandemic affected the level of income, where $54.20 \%$ of respondents experienced a decrease in income, which resulted in their investment activities. Among the respondents who experienced a decrease in income, $66.06 \%$ did not invest during the pandemic. It causes changes in people's behavior in determining investment instruments and avoiding high liquidity risk, which means people prefer investment instruments that are easy to liquidate (Media Indonesia, 2020), such as gold, savings, or time deposits, compared to investing in the stock market. In addition, the pandemic also impacts most industries which will most likely affect the decline in company profits, which will undoubtedly affect investors' decisions to invest in the stock market.

Danareksa Research Institute research also shows that $32.14 \%$ of people with decreased income, $40,74 \%$ people with regular income, and $82.14 \%$ people with increased income choose to invest long-term rather than take short-term profits obtained from dividend distribution events. It means that dividend announcements do not affect their investment decisions and prefer to invest in companies with good fundamentals and have good, long, and stable business continuity. The significant increase in capital market investors in 2020 means that there will be many novice investors during the pandemic. Research by Ganiarto et al., (2021) about novice investors to look at their investment behavior before and during the COVID-19 pandemic found that the harmful impact of the pandemic on the performance of various industries such 
as tourism and transportation influenced novice investors to delay investing in stocks.

This study shows that the dividend distribution event does not generate a significant difference in stock trading volume around the ex-date for both before and during the pandemic. The significant difference in the stock price around the ex-date was found before the pandemic, but not during the pandemic which is only found before the ex-date. Taking this study to note, the company's management may deliberate more on the announcement and ex-date on the dividend distribution event so the signals sent can be well responded to by the investors. The change in investment behavior and the investor preferences on the low dividend yield during the pandemic can be used by the management to reduce their dividend distribution and use their profit on the operation or investment.

\section{CONCLUSION AND SUGGESTION}

This study found a significant difference in the stock price before, during, and after the ex-date before the pandemic, which during the pandemic, the significant difference only found before the ex-date. The test results also show no significant difference in stock trading volume before, during, and after the exdate, either before or during the pandemic. No significant difference found in stock trading volume accompanied by gradually decreasing average abnormal return on the cum-date to the ex-date, as well as an increase in trading volume activity on the cum-date shows that research supports the dividend irrelevance theory, which states that dividend policy does not affect the stock market. The study also supports the clientele effect theory and the tax effect theory. Many investors avoid dividends, so they sell their shares on the cumdate to avoid dividends to save taxes. During the pandemic, investors change their investment behavior and prefer to invest in instruments with low liquidity risk.

For investors who expect profits from dividend distribution events, especially during a pandemic, taking profits from dividend distribution events is more challenging because there is no significant price difference. The returns obtained may not match the expected return, so they might need to change their investment strategy. This study result may not reflect the market reaction in the Indonesian market as a whole since this research is limited only to the IDX High Dividend 20 index, but it can show a glimpse of the market reaction is specific to the dividend distribution event.

This study only observed the ex-dividend phenomenon on IDX High Dividend 20 index, so it possibly does not fully reflect the condition in Indonesia. We also limit the event to ex-date and did not group the dividend event based on the increase and decrease of dividend amount.

\section{REFERENCES}

- Agarwal, S. (2020). A Conceptual study on Impact of Ex- Dividend Date at the Share Prices of the Stocks Listed under the Indian Tyre. International Journal for Research in Applied Science \& Engineering Technology, 8(IX), 527-538.

- Andini, N. W. L., Suputra, I. D. . D., \& Wirakusuma, M. G. (2017). Reaksi Harga Saham Saat Pengumuman Dividen Tunai Dimoderasi oleh Free Cash Flow. E-Jurnal Ekonomi Dan Bisnis Universitas Udayana, 11(6), 4015-4042.

- Anh, D. L. T., \& Gan, C. (2020). The impact of the COVID-19 Lockdown on Stock Market Performance : Evidence From Vietnam. Journal of Economic Studies. https://doi.org/10.1108/JES-062020-0312

- Campbell, J. A., \& Beranek, W. (1955). Stock Price Behavior on Ex-Dividend Dates. The Journal of Finance, 10(4), 425-429. https://doi.org/10.1111/j.15406261.1955.tb01295.x

- Capelle-Blancard, G., \& Desroziers, A. (2020). The Stock Market Is not the Economy? Insights from the COVID-19 Crisis. SSRN Electronic Journal, 2020(May),

$1-40$. https://doi.org/10.2139/ssrn.3638208

- Chen, H. L., Chow, E. H., \& Shiu, C. Y. (2013). Ex-dividend prices and investor trades: Evidence from Taiwan. Pacific Basin Finance Journal, 24, 39-65. https://doi.org/10.1016/j.pacfin.2013.02.004

- Cherkasova, V. A., \& Petrukhin, V. V. (2017). The ex-day phenomenon and share price performance on emerging markets. Journal of Corporate Finance Research, 11(1), 16-36.

- Darmawan. (2018). Volume Perdagangan. In Transaksi Saham Intrahari (p. 81).

- Dupuis, D. (2019). Ex-Dividend Day Price Behavior and Liquidity in a Tax-Free Emerging Market. Emerging Markets Review, 38, 239-250.

- Eugster, N., Ducret, R., Isakov, D., \& Weisskopf, J.-P. (2020). Chasing Dividends During the COVID-19 Pandemic. Working Paper SES, 520.

- Ganiarto, E., Komalasari, F., \& Manik, L. E. L. M. (2021). Novice Investor Behavior in Indonesia Stock Exchange: a Comparative Study Before and During Covid-19 Pandemic. FIRM Journal of Management Studies, 6(1), 107-123. http://ejournal.president.ac.id/presunivojs/index.php/FIR M-JOURNAL/article/view/1441

- García Blandón, J., Martínez Blasco, M., \& Argiles Bosch, J. (2011). Ex-dividend day returns when dividend and capital gains are taxed at the same rate. Finance a Uver - Czech Journal of Economics and Finance, 61(2), 140-152. https://doi.org/10.2139/ssrn.1911078

- Hartono, J. (2018). Studi Peristiwa (First). BPFEYogyakarta. 
- Hitten, A. (2016). Kebijakan Dividen dari Perspektive Agency Cost Model (Studi Kasus Perusahaan yang Terdaftar di Bursa Efek Indonesia periode 2011-2013). Jurnal Ekonomi Bisnis Dan Kewirausahaan, $\quad 5(1)$, 73. https://doi.org/10.26418/jebik.v5i1.16184

- Institute, D. R. (2020). DRI's Pulse Check: Pola Investasi Masyarakat Selama Pandemi.

- Isaksson, A., \& Islam, M. M. (2013). The ExDividend-Day Price Behaviour of Blue-Chip Stocks: International Evidence. Asian Journal of Finance \& Accounting, 5(1), 73-88. https://doi.org/10.5296/ajfa.v5i1.1948

- Istahargyo, B., \& Wirakusuma, M. G. (2019). Analisis Volume untuk Perbandingan Minat Investor Disekitar Ex-Dividend Date pada Emiten Kategori LQ-45 Tahun 2017. E-Jurnal Akuntansi Universitas Udayana, 26(1), 175-190.

- Kreidl, F. (2020). Stock-Market Behavior on ExDates: New Insights from German Stocks with Tax-Free Dividend. International Journal of Financial Studies, $8(3), \quad 58$. https://doi.org/10.3390/ijfs8030058

- Mahala, F. L., Zahroh, Z. A., \& Dwiatmanto. (2015). STOCK SPLIT ( Studi Pada Perusahaan Terdaftar Yang Melakukan Stock Split di Bursa Efek Indonesia tahun 2012-2014 ). Jurnal Administrasi Bisnis (JAB), 25(1), 1-7.

- Ngoc, D. B., \& Cuong, N. C. (2016). Dividend Announcement and Ex-Dividend Effects on Stock Return. International Journal of Economics and Finance, $\quad 8(7), \quad 207$. https://doi.org/10.5539/ijef.v8n7p207

- Nuraya, A. S., \& Larasati, Y. (2018). Analisis Perbedaan Abnormal Return Sebelum Dan Sesudah Pengumuman Ex - Dividend Date Pada Perusahaan Manufaktur di Bursa Efek Indonesia Periode Tahun 2011-2016. Jurnal Ekonomi, Manajemen Dan Perbankan, 4(2), 56-65.

- Nurfadillah, L. F., \& Nuzula, N. F. (2019). ANALISIS DAMPAK EX-DIVIDEND DATE PADA PEMBAYARAN DIVIDEN TERHADAP ABNORMAL RETURN (Studi Pada Perusahaan yang Terdaftar dalam Indeks IDX High Dividend 20 Tahun 2018). Jurnal Administrasi Bisnis (JAB), 72(1), 91-99. http://administrasibisnis.studentjournal.ub.ac.id/ind ex.php/jab/article/view/2843

- Octaviani, S., Widyanto, M. L., \& Helsinawati. (2019). Analysis of Comparison of Stock Return before and After Ex-Dividend Date in Industrial Property, Real Estate and Building Construction in Indonesia Stock Exchange Period 2013. East African Sholars Journal of Economics, Business and Management, 2(8), 447-451.

- Saleh, S. (2017). Analisis Data Kualitatif (H. Upu (ed.); 1st Editio). Pustaka Ramadhan. http://eprints.unm.ac.id/14856/1/ANALISIS DATA KUALITATIF.pdf

- Saraswati, H. (2020). Dampak Pandemi Covid-19 Terhadap Pasar Saham Di Indonesia. Jurnal Riset Akuntansi Dan Keuangan Dewantara, 3(2), 153163.

- $\quad$ Sih, T. M., Gumanti, T. A., \& Paramu, H. (2019). Analisis Perbedaan Abnormal Return dan Trading Volume Activity Pada Sekitar Cum Dividend Date ( Analysis of Differences Abnormal Return and Trading Volume Activity on Cum Dividend Date ). E-Journal Ekonomi Bisnis Dan Akuntasi, VI(1), 159-163.

- Tamara, T., Munir, Q., \& Maria, K. (2020). The ex-dividend-day behavior of stock prices and volume: The case of pharmaceutical dividend aristocrats. Singapore Economic Review, 65(4), 889-915. https://doi.org/10.1142/S0217590819500243

- Tambunan, D. (2020). Investasi Saham di Masa Pandemi COVID-19. Widya Cipta: Jurnal Sekretari Dan Manajemen, 4(2), 117-123. https://doi.org/10.31294/widyacipta.v4i2.8564

- Tandelilin, E. (2017). Pasar Modal: Manajemen Portofolio \& Investasi. PT. Kanisius.

- Tinashe, C. D. (2015). The Impact of Dividend Payments on Stock Prices in a Developing Economy . The case of Services Firms listed on the Zimbabwe Stock Exchange , ( 2008 to 2012 ). Case Studies Journal, 4(5), 126-133.

- www.mediaindonesia.com. (2020). Pandemi Ubah Perilaku Berinvestasi Masyarakat. Media Indonesia. https://mediaindonesia.com/ekonomi/320082/pande mi-ubah-perilaku-berinvestasi-masyarakat

Cite This Article: Ratna Suwendiyanti \& Rilla Gantino (2022). Analysis on Ex-Dividend Phenomenon before and During COVID-19 Pandemic in Indonesia (Study on Index IDX High Dividend 20). East African Scholars J Econ Bus Manag, 5(1), 1-10. 